\title{
Primary education in Nigeria at a glance: statistical overview of the subsector
}

\section{Resumen de la educación primaria en Nigeria: panorama estadístico del subsector}

Andrés Alberto Chávez Eras

Universidad Internacional del Ecuador, Ecuador

Autor para correspondencia: anchavezer@internacional.edu.ec

Fecha de recepción: 30 de Agosto de 2016 - Fecha de aceptación: 28 de Septiembre de 2016

\section{Resumen}

El siguiente estudio se enfoca en la educación primaria en Nigeria. Primeramente analizaremos los antecedentes políticos, económicos y sociales del país. Para con esto, poder tener un mejor entendimiento del sistema educativo. Se analizara los problemas con las finanzas, acceso y calidad de la educación.

Palabras claves: sistema educativo; áfrica; calidad educación

\begin{abstract}
The following study focuses on primary education in Nigeria. First we analyze the political, economic and social history of the country. For this, to have a better understanding of the education system. problems with finances, access and quality of education are analyzed.
\end{abstract}

Key words: education system; africa; quality education 


\section{Introduction}

Nigeria is the most populated country in Africa, with an estimated 174,507,539 people as of July 2013. Within this population, there are over 250 ethnic groups and 500 languages.

\section{Political Indicators}

Nigeria adopted a new constitution in 1999 that transitioned the country from military rule to a civilian government (Federal Republic of Nigeria, 2013). Now, the Federal Republic of Nigeria is a federal constitutional republic similar to the United States, with executive, legislative, and judicial branches. General elections are held every four years to choose a president (Federal Republic of Nigeria, 2013)._Despite the official government setup, Nigeria's scores on the Democracy Index indicate that the country is still far from functioning as a democracy, as seen in Table 1. All scores are out of a possible 10.0_(Philip \& Ojeka, 2011).

Table 1 Democracy Index for Nigeria

\begin{tabular}{llllllll}
\hline Year & Rank & $\begin{array}{l}\text { Overall } \\
\text { Score }\end{array}$ & $\begin{array}{c}\text { Electoral } \\
\text { Process and } \\
\text { Participation }\end{array}$ & $\begin{array}{c}\text { Functioning } \\
\text { of } \\
\text { Government }\end{array}$ & $\begin{array}{c}\text { Political } \\
\text { Participation }\end{array}$ & $\begin{array}{c}\text { Political } \\
\text { Culture }\end{array}$ & $\begin{array}{c}\text { Civil } \\
\text { Liberties }\end{array}$ \\
\hline $\mathbf{2 0 0 6}$ & 124 & 3.52 & 3.08 & 1.86 & 4.44 & 4.38 & 3.82 \\
$\mathbf{2 0 0 8}$ & 124 & 3.53 & 2.92 & 3.21 & 3.33 & 4.38 & 3.82 \\
$\mathbf{2 0 1 0}$ & 123 & 3.47 & 3.83 & 3.21 & 3.33 & 3.13 & 3.82 \\
\hline
\end{tabular}

Note. From "Democracy and Development: An Appraisal of Nigeria's Position in the Democracy Index" by C. Philip \& S. Ojeka, 2011, Research Journal of Finance and Accounting 2(2), p.4.

According to the Corruption Perceptions Index, Nigeria ranks 137 out of 176 countries, with a score of 27 out of 100 . People perceive the police and political parties to be the most corrupted institutions (Transparency International, 2013).

\section{Economic Indicators}

GDP per capita in Nigeria increased to 1,555.41 (US\$) in 2012. However, external debt stocks have risen as well. Nigeria was forgiven $\$ 30$ billion of debt in 2006, but has continued to accumulate debt since that time and had external debt stocks of $\$ 13,108$ billion in 2011 (World Bank, 2013).

In recent years, the amount of aid that Nigeria has received for education has increased significantly. As shown in Table 2, the amount received in 2010 was almost five times that which was received in 2002-2003.

Table 2 Total Aid to Education

\begin{tabular}{lll}
\hline Constant 2010 US\$ millions & & \\
\hline $\mathbf{2 0 0 2 - 2 0 0 3}$ annual average & 2009 & 2010 \\
$\mathbf{3 5}$ & 133 & 165 \\
\hline
\end{tabular}

Note. From EFA Global Monitoring Report 2012: YOUTH AND SKILLS Putting education to work p.402, by UNESCO, 2012, Paris: UNESCO. 
Table 3 shows the facts about the wellbeing of Nigeria's people. Over half of the population lives in absolute poverty, a significant percentage of people live in unsanitary conditions, and the life expectancy rate is much lower than that of developed nations. Additionally, only half of the population is literate.

Table 3 Nigeria Poverty Indicators

\begin{tabular}{lc}
\hline Poverty Indicator & $\mathbf{2 0 1 1}$ \\
\hline Life expectancy at birth & $53 \mathrm{yrs}$ \\
$\%$ of pop with access to improved water & $58 \% *$ \\
$\%$ of pop with access to improved sanitation & $31 \% *$ \\
$\%$ of pop with access to electricity* & $51 \%$ \\
Living in absolute poverty & $60.9 \% *$ \\
Children under 5 underweight & $26.7 * *$ \\
Literacy & $50.4 \%$ \\
& $(72.1 \%$ male $)$ \\
Unemployment rate & $(50.4 \%$ female) \\
\hline From Poverty in Nigeria, Noble Mission Organization, $2013 * 2010, * * 2008$
\end{tabular}

\section{Social Development}

The leading causes of death in Nigeria are HIV/AIDS, lower respiratory infections, malaria, diarrheal diseases, and measles, all of which are preventable or curable with the proper medicine and education (WHO, 2013). Lack of available and affordable treatments contribute to Nigeria's low life expectancy of 53 years, and the overwhelmingly young population shown in Figure 1. Many children become orphans at a young age and are forced to work and support siblings, which provides a barrier to participating in education.

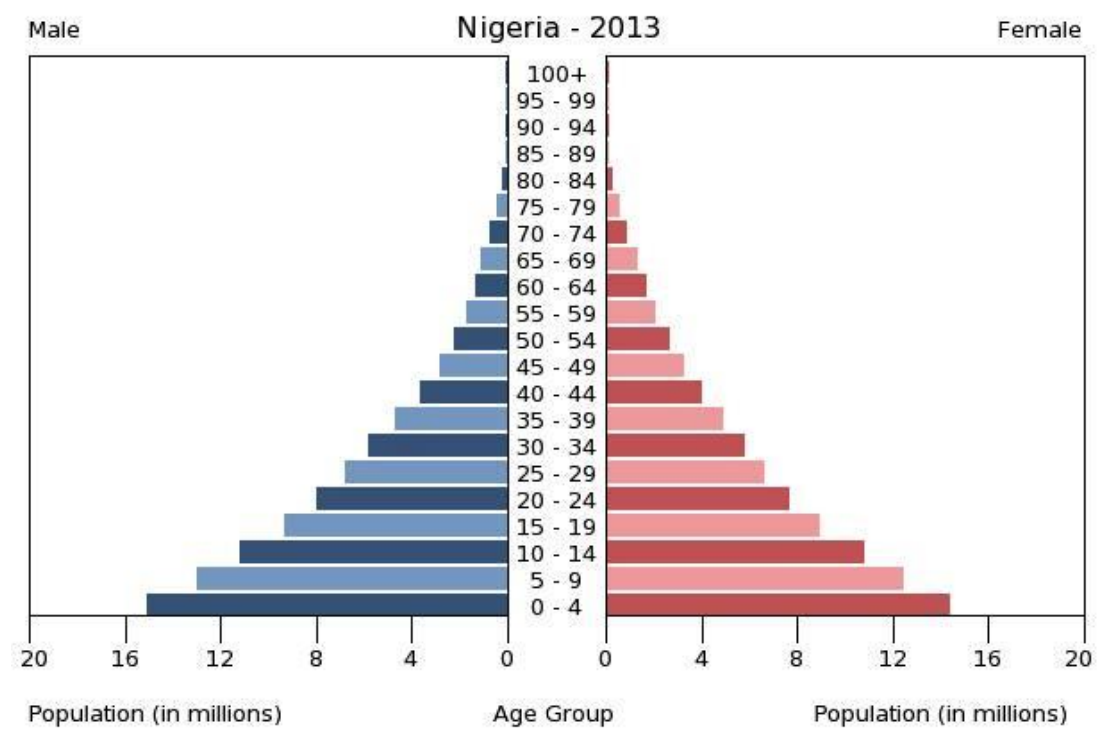

Figure 1 Nigeria Population Pyramid Graph. Adapted from "International Programs - Region Summary - U.S. Census Bureau”, 2013, U.S. Census Bureau. Copyright 2013 by U.S Census Bureau Reprinted.

There have been small but steady increases over the last several years in Nigeria in terms of HDI and its components. In 2012, the HDI was 0.47, Health was 0.510, Education was 0.457, 
and Income was 0.450 (HDR, 2013). As shown in Figure 2, gains in education have been the slowest and have leveled off in recent years.

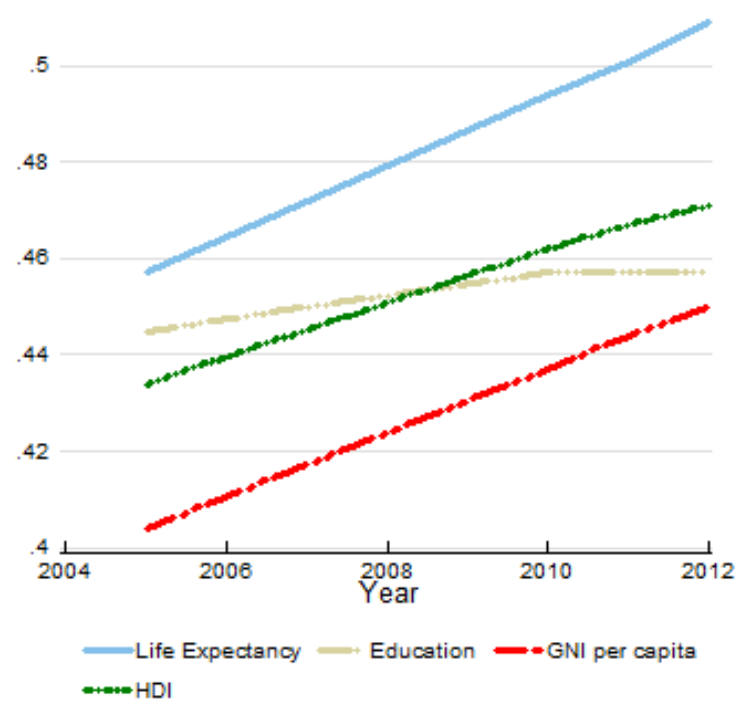

Figure 2. Trends in Nigeria's HDI component indices 2005-2012. Adapted from "Human Development Report 2013 Nigeria” 2013, Human Development Report. (HDR). Copyright 2013 by Human Development Report. Reprinted.

\section{The Education System}

The formal educational system in Nigeria presents various paths that students can take, starting with secondary education. At 12 years of age, children start either junior secondary or vocational enterprise institutions programs. If they attend the former, they receive a junior secondary school certificate upon completion; if they attend the latter, they receive a certificate of proficiency. At 15 years of age, students who have received a junior secondary school certificate may attend either senior secondary or secondary technical schools programs. Less than one-third of students who begin school in Nigeria go on to enroll in senior secondary school (Nigerian Education Profile, 2013).

Then, at age 18, the number of options increases for those students who completed senior secondary school and received either a West African senior school certificate or National examinations council certificate. However, in order to proceed to a tertiary institution, students must pass the Senior School Leaving Certificate; in 2010, $80 \%$ of students failed this certificate due to inability to pass English and Mathematics, among other subjects (Nigerian Education Profile, 2013). Students who are still deficient in some courses do have the opportunity to attend classes that will allow them to later matriculate in a university. There are also short certificate courses available that are oriented towards the labor market. Students may choose to enroll in bachelor programs, college and polytechnic programs, teacher training schools, or the school of nursing. Students who complete these programs may also be eligible to pursue further education, such as master programs, the higher national diploma, or a doctorate program. There are no postsecondary options available for students who complete vocational enterprise institutions programs or secondary technical schools programs (see Appendix A and Appendix B for more details). 
Table 4 presents the statistics for student enrollment in Nigeria. It is evident that although both primary and secondary education are labeled as compulsory, there are far fewer students participating in secondary education than those in primary education. The table also shows that despite the 500 languages that are spoken in Nigeria, children are instructed in three local languages at the beginning of their primary schooling, and then only in English after their third year of primary education.

Table 4 Nigeria: Country and Education System Vital Stats

\begin{tabular}{ll}
\hline Population & $\mathbf{1 7 4 . 5}$ million \\
\hline Language of Instruction & English (Hausa, Ibo and Yoruba in the first 3 years of primary) \\
Compulsory Education & Primary \& Lower Secondary School (Grades 1-9) \\
Academic Year & September to July \\
Number of Universities & 128 (51 private) \\
Number of Students & -Primary (6-12): 20,682,000 \\
& - Secondary (12-17): $9,057,000$ \\
& - Tertiary (18+): 1,700,000 \\
Lower Secondary Gross Enrollment Ratio & $47 \%$ \\
Secondary Gross Enrollment Ratio & $44 \%$ \\
Tertiary Gross Enrollment Ratio & $10 \%$ \\
\hline Note: From “An Overview of Education in Nigeria” by N. Clark \& C. Ausukuya, 2013, World Education News \& & Reviews, p.1.
\end{tabular}

The tracking system in Nigeria makes it difficult for many students to progress in the education system. Those who enroll in vocational programs at age 12 have no opportunity to receive the necessary certificates to one day participate in tertiary education. Much of these students' future is already decided from this young age, and it will be difficult for them to change their course once they are set in this path. The same is true for those students that begin technical programs at age 15 instead of attending senior secondary school.

\section{Education Finance}

\section{Indicators for the Subsector}

There is little reliable information available for financial expenditures in Nigeria. As one researcher found, even in official reports by UNESCO and World Bank "educational expenditure data for Nigeria are either totally omitted or are recorded for the Federal Government alone" (Hinchliffe, 2002). Another author warned, with regards to studies in Nigeria, that "it is important to remember that expenditure estimates are made on partial, often inadequate, data" (World Bank, 2008). With that in mind, the following represents the most recent available data from the region.

The federal budget for education decreased during the years of 2001-2004, but then began to increase significantly in 2006. Despite this increase in the overall budget, federal education allocation has failed to keep up with the growth that Nigeria has experienced in GDP. It has actually declined over time from $1.8 \%$ in 2001 to $1.4 \%$ in 2007 . The federal education budget, however, has risen slightly, from constituting $10.7 \%$ of the total federal budget in 2001 to $12.5 \%$ in 2007 (see Appendix C). 
Families contribute to the cost of education across all sectors. Table 5 shows the amount of money that families from varying socioeconomic backgrounds pay for different aspects of education, such as fees and books, as well as the percentage of families that pay for each category. It is notable that $93 \%$ of even the poorest families in Nigeria have to pay some type of expenditure for their children's education. Although primary education is supposed to be compulsory and free in Nigeria, almost half of the poorest families are still paying fees just so their children can attend primary school.

Table 5 Expenditures in Primary School, by Level of per Capita Expenditures

\begin{tabular}{|c|c|c|c|c|c|c|c|c|}
\hline $\begin{array}{c}\text { Quintile } \\
\text { and } \\
\text { Indicator }\end{array}$ & Fees & $\begin{array}{c}\text { Parent- } \\
\text { Teacher } \\
\text { association }\end{array}$ & Uniforms & $\begin{array}{c}\text { Book } \\
\text { and } \\
\text { supplies }\end{array}$ & Transportation & $\begin{array}{c}\text { Room } \\
\text { and } \\
\text { Board }\end{array}$ & Other & Total \\
\hline \multicolumn{9}{|c|}{ Amount spent (naira) } \\
\hline Poorest & 1,193 & 221 & 469 & 517 & 721 & 1,413 & 319 & 1,807 \\
\hline II & 1,566 & 179 & 585 & 539 & 1,169 & 1,910 & 618 & 2,217 \\
\hline III & 1,690 & 270 & 526 & 731 & 1,866 & 1,376 & 671 & 2,671 \\
\hline IV & 2,403 & 390 & 637 & 932 & 1,908 & 1,781 & 827 & 3,814 \\
\hline Richest & 5,351 & 442 & 817 & 1,354 & 2,999 & 3,089 & 1,590 & 7,718 \\
\hline \multicolumn{9}{|c|}{ Percentage paying } \\
\hline Poorest & 46 & 53 & 75 & 76 & 7 & 10 & 28 & 93 \\
\hline II & 45 & 53 & 75 & 81 & 8 & 8 & 30 & 95 \\
\hline III & 49 & 55 & 77 & 82 & 12 & 9 & 34 & 96 \\
\hline IV & 50 & 56 & 79 & 85 & 17 & 14 & 40 & 95 \\
\hline Richest & 67 & 53 & 81 & 85 & 22 & 13 & 44 & 96 \\
\hline Total & 51 & 54 & 77 & 82 & 13 & 11 & 35 & 95 \\
\hline
\end{tabular}

Note. From "Nigeria A Review of the Costs and Financing of Public Education" by World Bank, 2008, Human Development Unit Africa Region, 2, p.117.

Teachers in Nigeria are paid different amounts depending on the states in which they teach. Table 6 shows that there is a significant gap between these wages, ranging from 151,000 naira in Kaduna to 518,000 naira in Lagos. This difference equals approximately \$2,295 in US currency, and shows that teachers in some states make less than one-third of teachers in another.

Table 6 Average Annual Pay for Public Primary and teachers in SEPER States, 2005/06

\begin{tabular}{lccc}
\hline & $\begin{array}{c}\text { Annual Pay (naira } \\
\text { thousand rounded) }\end{array}$ & $\begin{array}{c}\text { As a percent of state per capital } \\
\text { household expenditure }\end{array}$ & $\begin{array}{c}\text { As a percent of per capital } \\
\text { national GDP }\end{array}$ \\
\hline State & & & 244 \\
Borno & 266 & 721 & 180 \\
Cross & 196 & 529 & \\
River & & & 279 \\
Enugu & 304 & 613 & 282 \\
FCT & 307 & 728 & 142 \\
Jigawa & 155 & 899 & 139 \\
Kaduna & 151 & 332 & 140 \\
Kano & 153 & 385 & 185 \\
Kwara & 201 & 893 & 476 \\
Lagos & 518 & 1,374 & \\
\hline
\end{tabular}

Note. From "Nigeria A Review of the Costs and Financing of Public Education" by World Bank, 2008, Human

\section{Access to Education}

Development Unit Africa Region, 2, p.102. 
The enrollment figures for each education sector are shown below in Table 7. Primary and secondary education are compulsory in Nigeria; as evidenced in the chart, primary school enrollment is quite high at around $83 \%$ of the population of children who are primary school age. However, the chart indicates that many students drop out before enrolling in secondary schooling. Only about $44 \%$ of students who enroll in primary education continue on to receive secondary education. It is interesting to note the rise in students who enroll in private schools at this age. Less than $3 \%$ of those students who begin primary education enroll in tertiary education.

Table 7 Education Enrollment by different Sectors

\begin{tabular}{llcll}
\hline $\begin{array}{c}\text { Education } \\
\text { Sector }\end{array}$ & $\begin{array}{c}\text { Age } \\
\text { Group }\end{array}$ & $\begin{array}{c}\text { School-age } \\
\text { population }\end{array}$ & $\begin{array}{c}\text { Total } \\
\text { Enrolment } \\
2010\end{array}$ & $\begin{array}{c}\text { Enrolment in private institutions as \% of } \\
\text { total enrolment - Median }\end{array}$ \\
\hline Pre-Primary & $3-5$ & --- & $2,021,000$ & 27 \\
Primary & $6-11$ & $24,835,000$ & $20,682,000$ & 8 \\
Secondary & $12-17$ & $20,560,000$ & $9,057,000$ & 22 \\
Tertiary* & $18-$ & 605,068 & 7.74 \\
\hline Note. From EFA Global Monitoring Report 2012: YOUTH AND SKILLS Putting education to work p.370, by \\
UNESCO, 2012, Paris: UNESCO. And From "Educational Financing Reforms in Nigeria: A Survey-Based Cost \\
Implications Analysis for University Education" by S. Akinyemi, I. Ofem, \& O. Adebisi, 2012, International \\
\multicolumn{5}{r}{ Journal of Humanities and Social Science, 2(15) p.162. }
\end{tabular}

Table 8 shows the average percentage of students who drop out in each grade during the 6 years of primary education. Dropout percentages are almost $6 \%$ higher for male students.

Table 8 Nigeria Dropout \%

\begin{tabular}{cccc}
\multicolumn{3}{c}{ Table 8 Nigeria } & Dropout $\%$ \\
\hline \multirow{3}{*}{ Duration of primary education } & \multicolumn{3}{c}{ Dropout all grades (\%) } \\
\cline { 2 - 4 } & Total & Male & Female \\
$\mathbf{6}$ & 20.1 & 22.7 & 17.0 \\
\hline
\end{tabular}

Note. From EFA Global Monitoring Report 2012: Youth And Skills Putting education to work p.362, by UNESCO, 2012, Paris: UNESCO.

This data seems to contradict the data presented in the previous table, which shows that less than half of the students enrolled in primary education continue on to secondary education. One possible explanation for this discrepancy is that a large number of students quit attending school upon completion of the primary school years.

There are fewer girls than boys enrolled in school in all sectors, but the gap decreases as the students progress through the education system. In 2010, there were 1,388,191 fewer girls enrolled in primary schools, and 359,959 fewer girls enrolled in secondary schools (see Appendix D).

There is a direct correlation between school attendance and socioeconomic status. As shown in Figure 3, students from the lowest quintile of socioeconomic background are almost three times times less likely to be enrolled in primary school than students from the highest quintile, and students between the ages of 12-17 in the lowest socioeconomic quintile are five times less likely to be enrolled in secondary school than students from the highest quintile. 
Appendix E shows more detail about how these inequities are spread across residence, region, and gender.

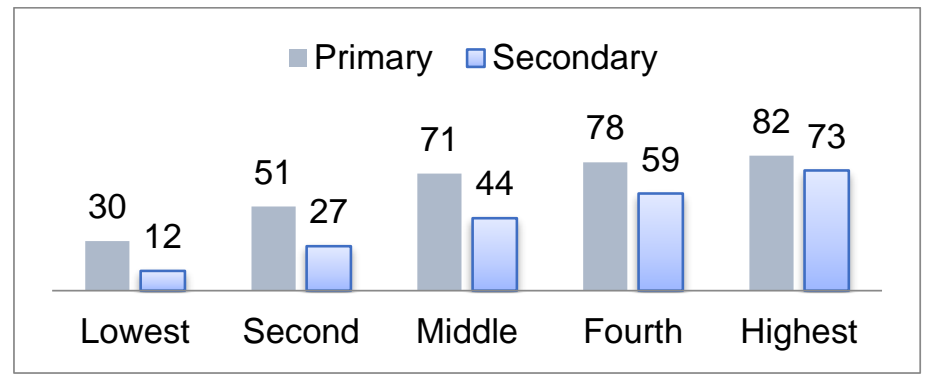

Figure 3 Primary and Secondary Net Attendance Ratio, by Economic Status Quintile Note. From Nigeria Demographic and Health Survey (DHS) EdData Profile 1990, 2003, and 2008: Education Data for DecisionMaking. 2011 p.57-58, by National Population Commission (Nigeria) and RTI International, 2011, Washington, DC: National Population Commission and RTI International.

\section{Quality of Education}

Over the last 20 years, there has been an increase in teachers in Nigeria, which has resulted in a decreased pupil/teacher ratio, as can be seen in Table 9. This is a positive change that can lead to increased quality of education, but it is not enough. The 2010 ratio of 36 students per teacher is still quite high.

Table 9 Pupil-Teacher Ratio

\begin{tabular}{cccc}
\hline \multicolumn{2}{c}{ Teaching Staff } & \multicolumn{2}{c}{ Pupil/teacher ratio } \\
\hline 1990 & 2010 & 1990 & 2010 \\
432000 & 574000 & 41 & 36 \\
\hline
\end{tabular}

Note. From EFA Global Monitoring Report 2012: Youth And Skills Putting education to work p.378, by UNESCO, 2012, Paris: UNESCO.

The percentage of qualified teachers in the workforce varies greatly by state in Nigeria. As seen in Table 10, there is an extremely low percentage of qualified teachers working in the rural areas of the Federal Capital Territory, whereas a fairly high percentage of teachers are qualified in the urban areas of the same region. Jigawa has the lowest overall percentages of qualified teachers, while Enugu and Lagos have the overall highest. As shown earlier in this paper in Table 6, teachers in Jigawa are among those who earn the least amount of money in Nigeria, and teachers in Enugu and Lagos make significantly more. This is an indication that students who live in poorer areas are less likely to be instructed by qualified teachers.

Table 10 Qualified Primary Schoolteachers in Select States, by Location 2005

\begin{tabular}{lcc}
\hline & \multicolumn{2}{c}{ Primary } \\
State and gender & Rural & Urban \\
\hline Borno & 41 & 47 \\
Female & 30 & 34 \\
Male & & \\
Cross River & 42 & 63 \\
Female & 46 & 53 \\
Male & & \\
Enugu &
\end{tabular}




\begin{tabular}{ccc}
\hline Female & 66 & 82 \\
Male & 61 & 69 \\
FCT & & \\
Female & 10 & 90 \\
Male & 17 & 72 \\
Jigawa & & \\
Female & 21 & 22 \\
Male & 17 & 32 \\
Lagos & & \\
Female & 66 & 69 \\
Male & 53 & 53 \\
\hline
\end{tabular}

Note. From "Nigeria A Review of the Costs and Financing of Public Education" by World Bank, 2008, Human Development Unit Africa Region, 2, p.179.

Nigeria participated in the MLA project in the 1990s along with 21 other Sub-Saharan and North African countries. Out of all the participating countries, the primary school students in Nigeria received the lowest scores, with an average of 30 percent. A comparison of their scores with the rest of the participants is shown in Figure 4.

Figure 4 Monitoring Learning Achievement in Sub-Saharan and North African Countries in $1990 \mathrm{~s}$

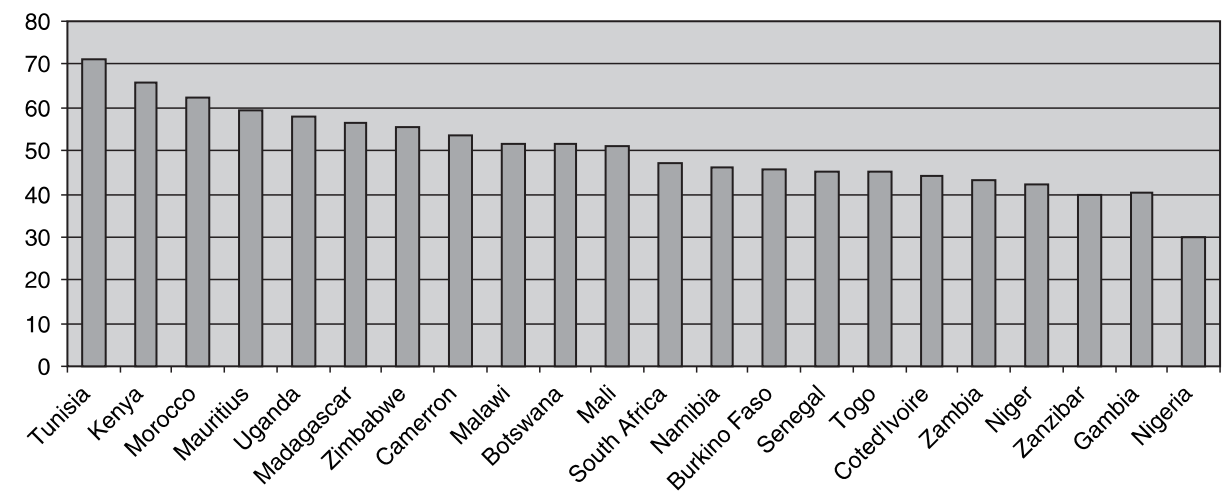

Figure 4. Monitoring Learning Achievement in Sub-Saharan and North African Countries in 1990s. Language, Literacy, and Learning in Primary Schools Implications for Teacher Development Programs in Nigeria (2007).

Note: From Africa Human Development Series, The World Bank, 96, p.6 by O. Adekola. Reprinted

These low scores indicate that Nigeria's education system is lacking. The students performed a full $10 \%$ below the next-lowest performing countries, which represents the largest gap between any two countries that participated. When the tests were administered again in the 2000s, results showed that Nigerian students made some slight improvements in the area of literacy, but otherwise continued to perform poorly (see Appendix F for scores from the 2003 exam). This lack of improvement indicates that the quality of education did not improve much over that decade.

\section{Proposed Focus of Subsector Review \& Limitations of Data}

The focus of my subsector review will be the problem of high dropout rates in primary education in Nigeria. I am choosing this focus because I have seen from my review that there are many factors that contribute to this problem, both stemming from the education system and family life, and I feel that there are plausible solutions to many of these issues. 
Some of the deficiencies in the education system that contribute to this problem are an insufficient amount of teachers, a lack of qualified teachers, required expenses that many families in poverty cannot afford, and instruction in a language (English) that children do not understand. These problems are more complex than they initially appear, and addressing them will obviously require collaboration with local stakeholders, but there are several possible ways to address these obstacles. These might include policies that would raise teacher salaries and provide incentives for teachers to become qualified. It may also be feasible to decrease the cost of education for families by eliminating school fees and providing textbooks free of charge. Additionally, policies regarding language of instruction could be altered in order to allow for more classes to be taught in students' native languages so that they feel more confident to succeed.

There are issues in Nigerian family life that contribute to the dropout rate as well. The life expectancy in Nigeria is only 53, so many children become orphans at a young age and are unable to continue their education. Additionally, with over half of the population living in extreme poverty, many families need their children to work and are unable to spare this extra income by sending them to school. Some possible solutions to these issues include improving access to health care and medicine in the country, as well as sanitary living conditions, so that the life expectancy can be increased. Also, there could be some changes made to the education system that would give poor families financial incentives to send their children to school, so that eventually they can become empowered to break the cycle of poverty through their education.

There is limited data available regarding budgets and finances in Nigeria, so it will be difficult to determine how the government can reallocate funds to address the issues that I have mentioned in this section. Most of the available data refer only to estimates rather than actual figures, and it is therefore unlikely that I will be able to present a clear picture of how the country is currently using its funds to support education, health reforms, and families in poverty.

\section{Bibliography}

Adekola, O. (2007). Language, Literacy, and Learning in Primary Schools Implications for Teacher Development Programs in Nigeria. Africa Human Development Series, The World Bank 96, 1-78. Retrieve October 4, 2013 from https://openknowledge.worldbank.org/handle/10986/6737

Akinyemi S., Ofem I. B., and Adebisi O. (2012) Educational Financing Reforms in Nigeria: A Survey-Based Cost Implications Analysis for University Education, International Journal of Humanities and Social Science, 2(15) 155-165.

Clark, N., \& Ausukuya, C. (2013) World Education News \& Reviews (WENR). An Overview of Education in Nigeria. Retrieved October 20, 2013, from http://wenr.wes.org/2013/07/anoverview-of-education-in-nigeria/

Federal Republic of Nigeria. (2013). About Nigeria. Retrieved October 18, 2013, from www.nigeria.gov.ng/2012-10-29-11-05-46 
Hinchliffe, K. (2002). Public Expenditures on Education in Nigeria: Issues, Estimates and Some Implications Keith Hinchliffe Africa Region. Abuja: Human Development Sector Africa Region The World Bank. Retrieve October 4, 2013 from http://siteresources.worldbank.org/ AFRICAEXT/Resources/no_29.pdf

Human Development Report. (HDR). (2013). Human Development Report 2013 Nigeria. Retrieved October 17, 2013, from hdrstats.undp.org/images/explanations/NGA.pdf

Mamedu, A., \& Wetheridge, L. (2013). Transforming education for girls in Nigeria: Endline research summary report. Abuja: ActionAid.

National Population Commission (Nigeria) and RTI International. (2011). Nigeria Demographic and Health Survey(DHS) EdData Profile 1990, 2003, and 2008: Education Data for Decision-Making. 2011. Washington, DC: National Population Commission and RTI International.

Nigerian Education Profile - United States Diplomatic Mission to Nigeria. (2013). United States Diplomatic Mission to Nigeria. Retrieved October 20, 2013, from http://nigeria.usembassy.gov/nigeria_education_profile.html

Noble Mission Organization. (2013). Poverty in Nigeria. Retrieved October 20, 2013, from http://www.noblemissions.org/index.php/program-news/21-poverty-in-nigeria

Onyukwu, J. (2012). World Education News \& Reviews (WENR). The Educational System of Nigeria. Retrieved October 20, 2013, from http://wenr.wes.org/2011/08/wenr-julyaugust2011-practical-information/

Philip, C. O., \& Ojeka, S. A. (2011). Democracy and Development: An Appraisal of Nigeria's Position in the Democracy Index. Research Journal of Finance and Accounting, 2(2), 1-6.

Transparency International. (2013). Transparency International. Retrieved October 18, 2013, from www.transparency.org/country\#NGA

U.S. Census Bureau. (2013). International Programs - Region Summary - U.S. Census Bureau. $\begin{array}{llll}\text { Retrieved } \quad \text { October } & 20, & \text { from }\end{array}$ http://www.census.gov/population/international/data/idb/region.php?N=\%20Results\%20\& $\mathrm{T}=12 \& \mathrm{~A}=$ separate $\& \mathrm{RT}=0 \& \mathrm{Y}=2013 \& \mathrm{R}=-1 \& \mathrm{C}=\mathrm{NI}$

UNESCO. (2012). EFA Global Monitoring Report 2012: Youth And Skills Putting education to work. Paris: UNESCO. Retrieve October 4, 2013 from http://unesdoc.unesco.org/images/0021/ 002180/218003e.pdf

UNESCO. (2013). UNESCO Institute for Statistic. Isced Mappings . Retrieved October 20, 2013, from http://www.uis.unesco.org/Education/ISCEDMappings/Pages/default.aspx 
World Bank. (2008). Nigeria A Review of the Costs and Financing of Public Education. World Bank - Human Development Unit Africa Region, 2, 1-190.

World Bank. (2013). International Debt Statistics 2013. Washington, D.C.: World Bank.

World Health Organization (WHO). (2012). WHO Nigeria. WHO African Region: Nigeria. Retrieved October 18, 2013, from www.who.int/entity/healthinfo/statistics/bodgbddeathdalyestimates.xis 


\section{Appendix A}

\section{Nigeria ISCED Mapping}

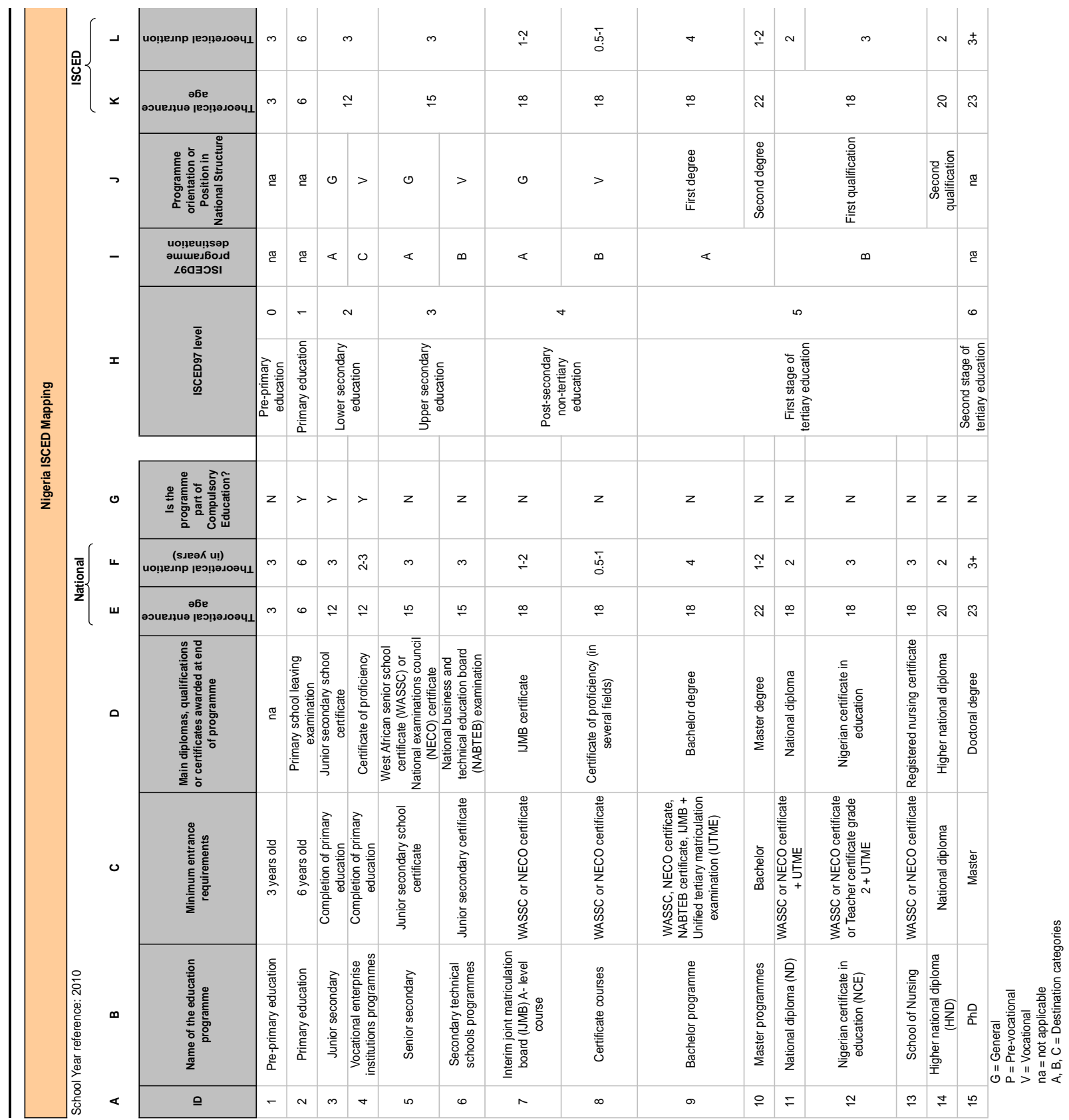

Note. From ISCED MAPPINGS, UNESCO Institute for Statistic, by UNESCO, 2013. 


\section{Appendix B}

Education System and Qualification Structure

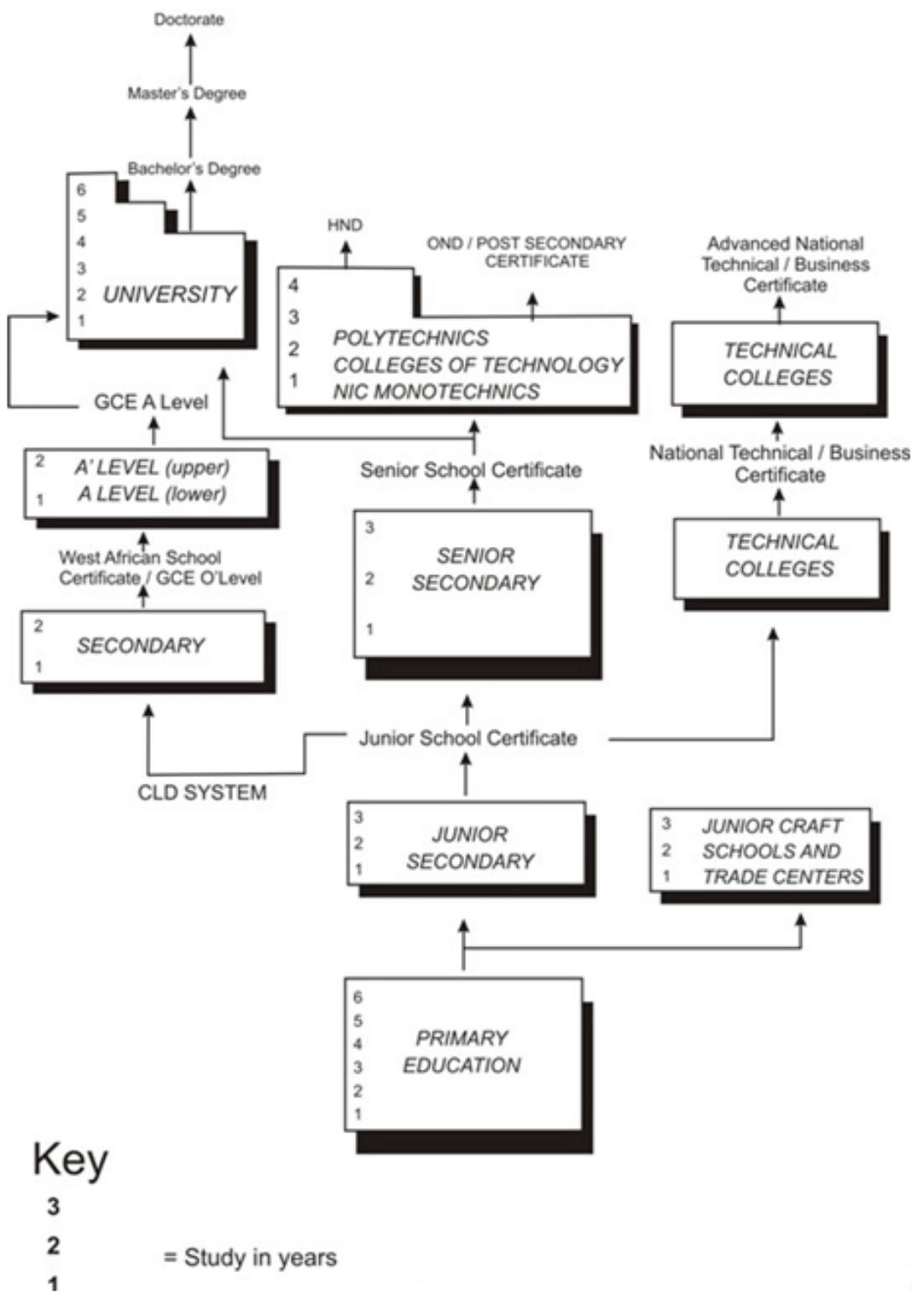

Note. From The Educational System of Nigeria, by J. Onyukwu, 2012, World Education News \& Reviews (WENR)

\section{Appendix C}

Federal Government and ETF Allocations to Education, 2001-07 real 2006 naira, billions, unless otherwise noted

\begin{tabular}{llllllll}
\hline Indicator & $\mathbf{2 0 0 1}$ & $\mathbf{2 0 0 2}$ & $\mathbf{2 0 0 3}$ & $\mathbf{2 0 0 4}$ & $\mathbf{2 0 0 5}$ & $\mathbf{2 0 0 6}$ & $\mathbf{2 0 0 7}$ \\
\hline $\begin{array}{c}\text { Total federal } \\
\text { education budget } \\
\text { allocation }\end{array}$ & 176.6 & 150.7 & 143.0 & 126.4 & 168.2 & 215.2 & 230.6 \\
\hline
\end{tabular}




\begin{tabular}{|c|c|c|c|c|c|c|c|}
\hline $\begin{array}{l}\text { Education Trust } \\
\text { Fund }\end{array}$ & 17.7 & 31.2 & 14.2 & 14.2 & 24.3 & 23.7 & - \\
\hline $\begin{array}{l}\text { Total federation } \\
\text { allocation to } \\
\text { education }\end{array}$ & 194.3 & 181.9 & 157.2 & 140.6 & 192.5 & 238.9 & - \\
\hline $\begin{array}{l}\text { Total federal } \\
\text { government budget }\end{array}$ & $1,648.5$ & $1,748.8$ & $1,237.1$ & $1,217.2$ & $1,430.0$ & 1627.1 & $1,849.2$ \\
\hline GDP & $10,082.5$ & $9,422.4$ & $11,051.1$ & $12,214.7$ & $14,059.9$ & $15,260.7$ & $16,691.0$ \\
\hline $\begin{array}{l}\text { Total federal } \\
\text { education budget as } \\
\text { a percent of total } \\
\text { budget }\end{array}$ & 10.7 & 8.6 & 11.6 & 10.4 & 11.8 & 13.2 & 12.5 \\
\hline $\begin{array}{l}\text { Total federal } \\
\text { education allocation } \\
\text { as a percent of total } \\
\text { budget and } \\
\text { Education Trust } \\
\text { Fund }\end{array}$ & 11.7 & 10.2 & 12.6 & 11.4 & 13.2 & 14.5 & - \\
\hline $\begin{array}{l}\quad \text { Total federal } \\
\text { government } \\
\text { allocation to } \\
\text { education as a } \\
\text { percent of GDP }\end{array}$ & 1.8 & 1.6 & 1.3 & 1.0 & 1.2 & 1.4 & 1.4 \\
\hline $\begin{array}{l}\text { Total federation } \\
\text { allocation to } \\
\text { education as a } \\
\text { percent of GDP }\end{array}$ & 1.9 & 1.9 & 1.4 & 1.2 & 1.4 & 1.6 & - \\
\hline
\end{tabular}

\section{Appendix D}

National enrolment in public primary and junior secondary schools over time Primary Schools

\begin{tabular}{lllll}
\hline Year & Male & Female & Male & Female \\
\hline $\mathbf{2 0 0 7}$ & $11,086,997$ & $9,382,398$ & $1,688,295$ & $1,310,077$ \\
$\mathbf{2 0 0 8}$ & $10,252,000$ & $8,728,395$ & $1,899,060$ & $1,552,018$ \\
$\mathbf{2 0 0 9}$ & $10,154,860$ & $8,663,684$ & $2,081,305$ & $1,676,788$ \\
$\mathbf{2 0 1 0}$ & $10,215,179$ & $8,826,988$ & $2,260,585$ & $1,864,626$ \\
\hline
\end{tabular}

Note. From Transforming education for girls in Nigeria: Endline research summary report. P.7, by A. Mamedu \& L. Wetheridg, 2013, Abuja: ActionAid.

\section{Appendix E}

Primary school net and gross attendance ratios

Primary net attendance ratios (NAR), gross attendance ratios (GAR), and the gender parity index

(GPI) for the de jure household population age 5-24, by sex, according to background characteristics, 2008 NDHS

\begin{tabular}{|c|c|c|c|c|c|c|c|}
\hline Background Characteristics & \multicolumn{3}{|c|}{ Net Attendance Ratio (NAR) } & \multicolumn{3}{|c|}{$\begin{array}{c}\text { Gross Attendance Ratio } \\
\text { (GAR) }\end{array}$} & $\begin{array}{l}\text { Gender } \\
\text { Parity }\end{array}$ \\
\hline Residence & Male & Female & Total & Male & Female & Total & Index \\
\hline
\end{tabular}




\begin{tabular}{llllllll}
\hline Urban & 75.7 & 73.0 & 74.4 & 101.4 & 96.7 & 99.0 & 0.95 \\
Rural & 58.5 & 52.2 & 55.4 & 85.0 & 73.6 & 79.3 & 0.87 \\
Region & & & & & & & \\
North Central & 67.7 & 65.2 & 66.4 & 99.5 & 92.8 & 96.1 & 0.93 \\
North East & 43.5 & 38.0 & 40.8 & 64.7 & 53.3 & 59.0 & 0.82 \\
North West & 46.7 & 35.5 & 41.0 & 68.2 & 48.9 & 58.5 & 0.72 \\
South East & 80.3 & 80.0 & 80.1 & 112.5 & 112.1 & 112.3 & 1.00 \\
South South & 79.3 & 79.9 & 79.6 & 110.7 & 111.7 & 111.2 & 1.01 \\
South West & 90.2 & 78.0 & 79.1 & 105.4 & 101.9 & 103.6 & 0.97 \\
Economic status quintile & & & & & & & \\
Lowest & 34.0 & 26.7 & 30.5 & 52.7 & 40.1 & 46.4 & 0.76 \\
Second & 55.4 & 47.5 & 51.4 & 83.8 & 68.6 & 76.2 & 0.82 \\
Middle & 73.9 & 68.1 & 71.1 & 106.6 & 97.1 & 101.8 & 0.91 \\
Fourth & 79.9 & 76.3 & 78.1 & 109.2 & 103.1 & 106.1 & 0.94 \\
Highest & 82.1 & 81.0 & 81.6 & 103.5 & 101.9 & 102.7 & 0.98 \\
& & & & & & & \\
Total & 63.5 & 58.4 & 61.0 & 89.8 & 80.5 & 85.1 & 0.90 \\
\hline
\end{tabular}

Note. From Nigeria Demographic and Health Survey (DHS) EdData Profile 1990, 2003, and 2008: Education Data for Decision-Making. 2011 p.58, by National Population Commission (Nigeria) and RTI International, 2011, Washington, DC: National Population Commission and RTI International.

\section{Appendix F}

UBEC National Assessment of Learning Achievement in Grades 4, 5, and 6 in 2003

\begin{tabular}{llll}
\hline & Grade 4 & Grade 5 & Grade 6 \\
\hline English language & 25 & 25 & 21 \\
Mathematics & 37 & 37 & 36 \\
Primary Science & 40 & 39 & 40 \\
Social Studies & 25 & 26 & 21 \\
\hline
\end{tabular}

Note: From "Language, Literacy, and Learning in Primary Schools Implications for Teacher Development Programs in Nigeria" by O. Adekola, 2007, Africa Human Development Series, The World Bank, 96, p.7. 